\title{
The Role of Triple Helix Actors for Agro Tourism Development in West Sumatera
}

\author{
WIDYA FITRIANA \\ Sosial Ekonomi Pertanian Universitas Andalas, Sumatera Barat \\ email: widyafitriana66@gmail.com
}

\begin{abstract}
Agricultural sector as a main contributor to GDP formation in West Sumatera is required to be able to diversify its business in order to achieve the highest economic and social development. One diversified agricultural business prospective to be developed is agro-tourism. The development of agro-tourism requires collaboration and synergy among academician, businessman, and government which known as triple helix actors. This study is designed with aim to (i) map the agro-tourism potential in West Sumatera; (ii) analyze the role of each actors which may allow them to take action in accelerating Agro-tourism development. This research uses observation, depth interview method, literature study, and focus group discussion. The result shows that agro-tourism in West Sumatra is prominent for its great natural and cultural value, but small in scale and lack of local facilities. It also requires relatively high level of investment for its capital return. Therefore, government support is an essential element in developing agro-tourism and the effort may also be better directed toward consolidating with intellectual and business.
\end{abstract}

Keywords: agro-tourism, rural development, role of triple-helix

\section{Introduction}

Creative economic development in West Sumatra has been more prominent in industrial-crafts and culinary arts. The development of this sub-sector is quite rapid and even has been known in the international market. Nevertheless, based on national statistics, the value of handicrafts export tends to decrease due to the aggressive entry of new competitors, China and Thailand, into international market. In response to this, West Sumatra needs to find a new icon for more competitive and creative economic development, and one potential alternative solution is to develop agro-tourism. Agrotourism is one form of creative economic development in agriculture. Agro-tourism development in West Sumatra has enough potential to be developed based on natural resources and unique local cultures. Each district /city has its own peculiarities onfarm, cultural values, and traditions inherent in agricultural activities. This becomes a potential asset for agro-tourism development. It is expected to give a multiplier effect to accelerate regional economic growth through increasing the income of farmers and rural communities, absorbing labor, preserving image and value of local culture, the growth of business and investment, and also poverty reduction.

Agro-tourism is a hybrid concept that merges elements of two complex industries -agriculture and tourism- to open up new profitable markets for farm products \& services as well as provide a market for tourists. It is important to consider these factors in planning and developing agro-tourism as a rural business (Mahaliyanaarachchi, 2015). Refers to "The development of creative economy Indonesia 2025" by the Ministry of Trade Republic Indonesia (2008), creative economic development in Indonesia requires a symbiotic mutualism among three main actors: the government, academician, and businessman. This relationship is known as the triple helix models. Theories about the triple helix was originally popularized by Etzkowitz \& Leyderdorff as a method-based on innovation policy. This theory reveals

Received: January 03, 2017, Revision: July 25, 2017, Accepted: December 14, 2017

Print ISSN: 0215-8175; Online ISSN: 2303-2499. DOI: http://dx.doi.org/10.29313/mimbar.v33i2.2098.219-227

Accredited B based on the decree No.040/P/2014, valid on February, 18, 2014 until February, 18, 2019. Indexed by DOAJ, Sinta, IPI 
the importance of creating synergy of three actors namely academician, businessman, and government. The development of agrotourism as a rural development strategy would require an understanding of the role of each actor in forming a synergistic relationship. The Triple Helix model is increasingly relevant as a conceptual framework for regional development. Its capacity to describe the process as the result of the joint workings of the University, Industry, and Government institutional spheres is expanded by introducing the novel concept of "Triple Helix Spaces":

Knowledge, Innovation and Consensus Spaces, which show the process and mechanisms by which the institutional spheres interact and co-evolve over time (Etzkowitz, 1993).

This study aims to (a) map the role of each actor of triple helix and (b) to make the awareness of their roles and allow each actors to take action in accelerating agro-tourism development in West Sumatera. Therefore, the result can be used to provide the recommendation for related stakeholders in order to establish collaboration and synergies in developing agro-tourism in West Sumatera

Most of the alternative tourism approaches are closely related to rural economy and thereby rural development. The main reason for this is the tourist destination of this alternative tourism approach takes place in rural areas. Therefore, agro-tourism as an alternative tourism creates a new economic opportunity in rural areas as well as to the macroeconomy of a country (Mahaliyanaarachchi, 2015).

According to Mutana (2013), Agrotourism is one of the many pro-poor strategies which have success stories in reducing extreme poverty. It is credited for poverty reduction in Uganda (Lepp, 2004), South Africa (Mafunzwaini and Hugo, 2005), Namibia (Ashley, Boyd and Goodwin (2000), India and Philippines (Ashley et al, 2000). Rural tourism is particularly relevant in Southern Africa given the challenge of economic and political transformations currently taking place in most Southern African countries (Ashley and Roe, 2002). Rural tourism development in the village of Fundata did not affect the beauty of the local landscape (Balan \& Burghelea, 2015). Certain characteristics of tourism create a development tools of choice in the rural areas. They are labor intensive, inclusive of women, and informal sector based on natural and poor cultural assets and suitable for poor rural areas with few other growth options (Ashley and Roes, 2002; Mafunzwaini and Hugo, 2005)

Triple helix is one of the concepts used in agro-tourism development models. The concept of the Triple Helix of Business-IndustryGovernment relationships developed in the 1990s by Etzkowitz (1993) and Etzkowitz and Leydesdorff (1996), encompassing elements of precursor works by Lowe (1982) and Sábato and Mackenzi (1982), interprets the shift from a dominating industry-government dyad in the industrial society to a growing triadic relationship between businessmanacademician-government in the knowledge society. Through subsequent development (e.g. Etzkowitz and Leydesdorff, 1998, 2000; Leydesdorff, 2006) the concept has grown into a conceptual framework for exploring the complex dynamics of the knowledge society and informing policy makers at national, regional, and international level in the design of new innovation and development strategies (Ranga \& Etzkowitz, 2012)

Triple helix models can be elaborated in various directions (Laydesdorff, 2012). Firstly, the networks of businessman-academiciangovernment relations can be considered as neo-institutional arrangements which can be made the subject of social network analysis. This model can also be used for policy advice about network development, for example in the case of transfer of knowledge and the incubation of new industry. The new and potentially salient role of universities in knowledge-based configurations can be explored in terms of different sectors, regions, countries, etc. (Godin \& Gingras, 2000; Shinn, 2002). Over the past ten years, this neoinstitutional model has also been developed into a discourse about "entrepreneurial universities" (Etzkowitz, 2002; Mirowski \& Sent, 2007). Regions are then considered as endowed with intellectual actor which can be optimized for a third mission, and different from higher education and internationally oriented research. Secondly, the networks span an architecture in which each relation occupies a position. Thus, One can obtain a system perspective on knowledge-based innovation in a hypothesized space; this theoretical construct the knowledge-based economy that can be informed by systematic data analysis (Leydesdorff\& Fritsch, 2006).

In the other side, Sarpong, Meisnerr, Wales and Alexander (2016) call the creation of new meaning in the redefinition of business-intellectual and government interaction, cooperative relationship and 
collaboration. Thus, the universities will begin to corporatize their activities, broaden their engagement with industries, and put a premium on mutually agreed collaboration with external partners in developing and probing emerging technologies. The redefinition of the collaborative relationships could then lead to radical changes in the national innovation and collaboration arrangements protocols in ways to strengthen the interdependence of institutions as they seek to achieve transformative synergies (Figure 1).

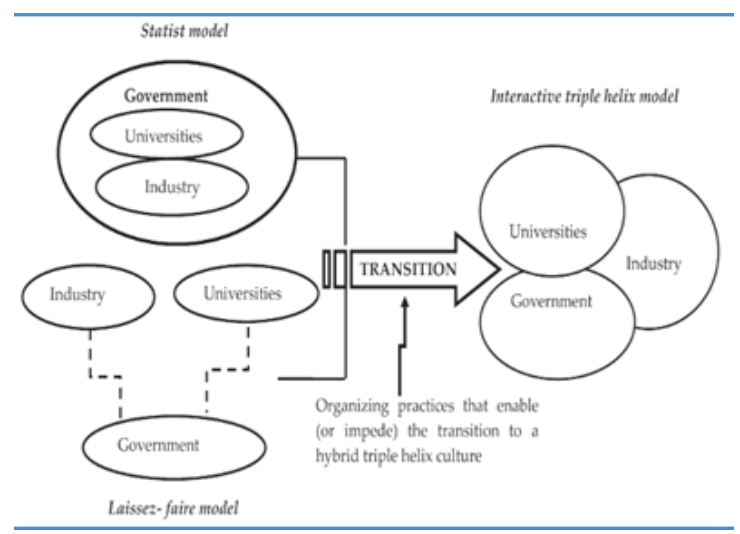

Figure 1. Patents of triple helix interactions (source: Sarpong, Meissner, Wales, Alexander. 2016)

In the context of agro-tourism, triple helix interactions play an important role for the successful of agro-tourism development. It needs to view agro-tourism not only from internal perspective (local community) but also from external stakeholders (tourist) perspective. The innovation of successful agro-tourism development could not go partially, it must be collaboration among academician, businessman and government. This may involve the performative integration of natural and cultural values, experiences and activities of partners in ways to support agro-tourism enterprise and the new spirit of collaboration of triple helix actors. Therefore, the purpose of this research is to develop a framework of triple helix interactions for agro-tourism development in West Sumatera.

\section{Methodology of Research}

The research used qualitative approach in order to be meaningful and appropriate to advance insight into the organizing practices of three triple helix actors. In this regard, qualitative methods of data collection were used to help researcher capture the triple helix roles in agro-tourism development in West Sumatera. Research technique used qualitative data in the form of primary and secondary data. The primary data were collected through in-depth-interview with structured questionnaire and focus group research. Secondary data was obtained by collecting journal and relevant literatures.

According to Muslim (2016) qualitative research with phenomenological approach has four advantages. Firstly, it can be the source of more entrenched description and explanation, particularly concerning the occurring process in the local context. Secondly, it can build the closer relationship with informants as the target of study. Thirdly, it gives the author the opportunity of disclosing the chronology of social events, assessing and giving an explanation about the causal relationship occurring in a local event. Fourthly, it is easier to answer the problem posed.

Target objects of this research are experts in each triple helix actors. The data were collected by doing observation, interview, documentation, and applying questionnaire techniques. The questionnaire in this quantitative research was used for the survey in order to complete the primary data. The questions were developed through expert discussion to provide the main concept of agro-tourism development in West Sumatera and the role of each actor in triple helix. In this study, we interviewed 6 actors: 2 from academicians, 2 from businessmen, and 2 from government. The research participant spent an average of more than 5 years working in their institution. Data validation was carried out through persistent observing and examining the data with triangulation. All data were analyzed qualitatively through three ways: data reduction, data presentation, and conclusion or verification (Miles \& Huberman, 1984).

\section{The Potential Agro-Tourism in West Sumatera}

Agro-tourism is a hybrid concept that merges elements of two complex industries -agriculture and tourism- to open up new profitable markets for farm products \& services as well provide a market for rural tourists and travelers. It is important to consider these factors in planning and developing agro-tourism as a rural business (Mahaliyanaarachchi, 2015). Agro-tourism is now thought to be one of the most effective way to reenergize and restructure lagging rural economies through its synergistic effects. However, as with some tools, it 
must be applied carefully to the job of which it was intended. Not all aspects of agrotourism apply in all contexts. The success of rural tourism in certain contexts has led to widespread rhetorics about its effectiveness (Risteski, Kocevski, Arnaudov, 2012). It also point out that agro-tourism will be sustainable if the development consists of three important aspects: environment, social, and economy. High expectations often lead to disappointment when enthusiasts realize the gap that often exists between reality and promise.

The potential Agro-tourism in West Sumatera can be classified into three resources: (a) Natural resources tourism; (b) Flora and Fauna resources tourism; and (c) Socio-cultural resources tourism. Natural resources tourism is more prominent in great natural resources, such as waterfall, caves, rice terraces, natural forests, and many more.

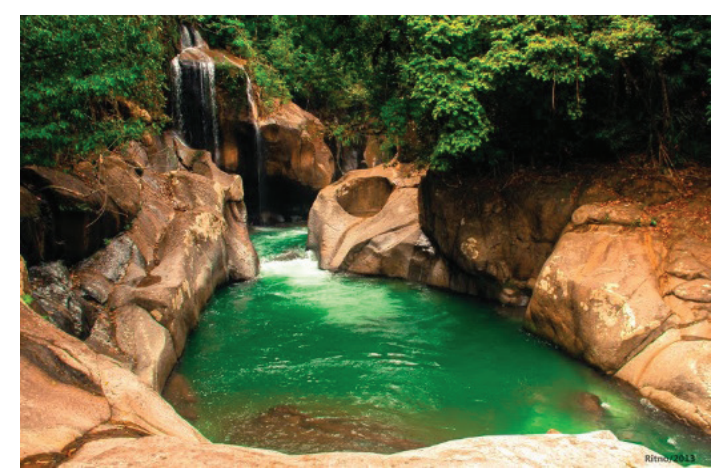

Figure 2. Waterfall

(source:http://lubuk aluang.blogspot. co.id/2013/05/air-terjun-nyarai.html)

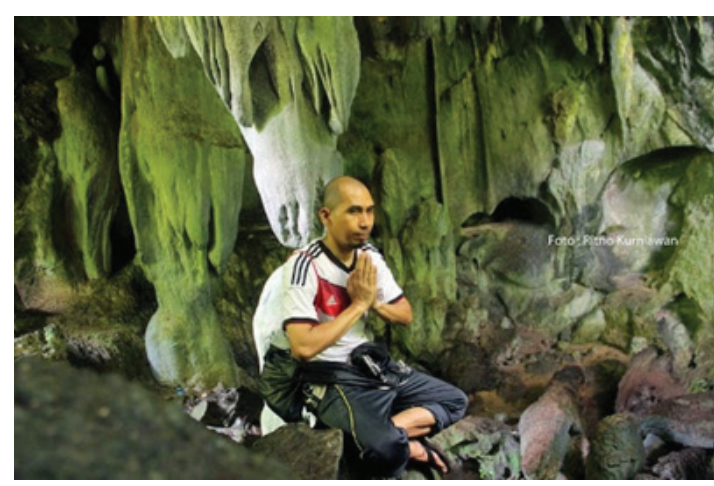

Figure 3. Caves

(source:http://lubuk-aluang.blogspot. co.id/2015/05/gua-ngalau-aie-ilang-kini. html)

The natural potential owned is still very original and have difficult route since there is no access road that can be passed by public transportation. Agro-tourism based on natural attraction such as waterfall, forest, and cave is far from the local people's house and has a lack of infrastructure and facilities, less affordable, and no road access.

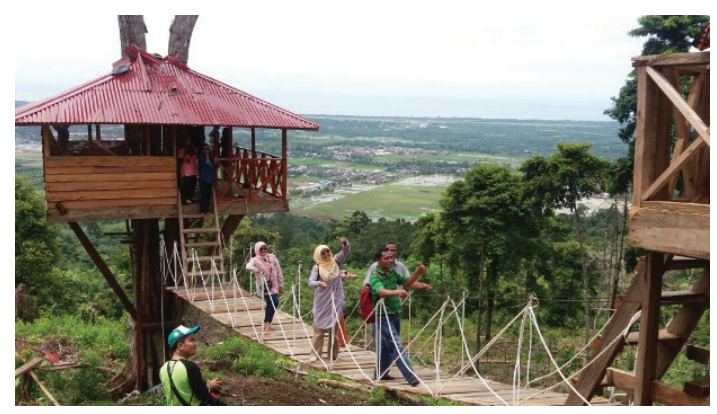

Figure 4. Forest

(source: http://www.sumbarprov.go.id/ details/news/8990)

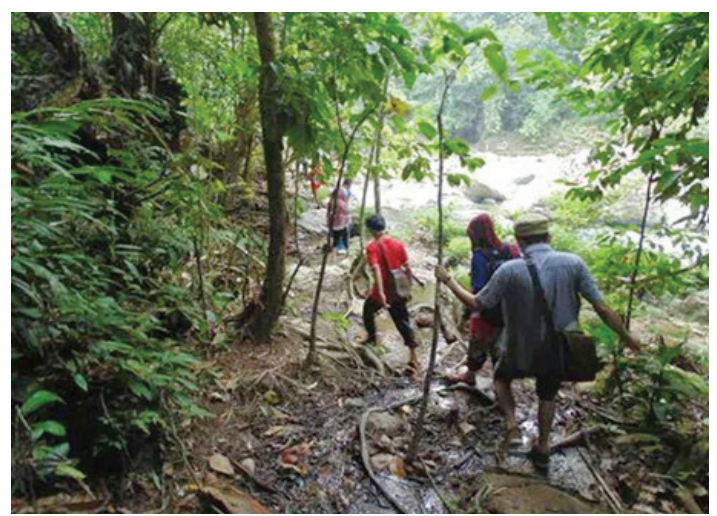

Figure 5. Road to tourist site

West Sumatra also has a rich potential of flora and fauna resources which can be developed as agro-tourism destinations such as endemic bilih fish in singkarak lake, or grassland tourism and cattle ranch in Padang Managateh, Limapuluh Kota.

Beside flora, fauna and natural view, West Sumatera also has uniqueness socialcultural activities that can invite tourism. Pacu Jawi and Tabuik are famous traditional events of cultural attractions performed yearly. Pacu Jawi is a cultural heritage and attraction in a form of race (runway) cows in rice fields after harvesting time or when entering time planting which is regularly held in four subdistrict/kampong/nagari in West Sumatera such as Tanah Datar (Nagari), Sungai Tarab, Lima Kaum, Rambatan and Pariangan. Pacu Jawi held as a symbol of thanksgiving for paddy rice yields, constructive spirit of mutual cooperation in local society, egalitarian values and togetherness, preserving social capital, folk entertainment, building networks, full of aesthetic aspects and harmony with natural beauty, and highly coveted by professional photographers for photo contest in national 
and international event. In rural tourism, the "sense of place" is a fundamental element in both tourists and host community's feelings of what makes the area attractive to visit and live in. This sense of place is maintained partly through pacu jawi attraction which plays a vital role in preserving Minangkabau's heritage.

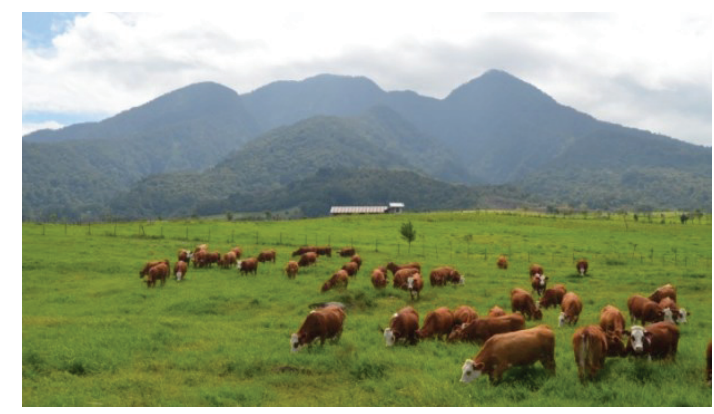

Figure 6 Grassland tourism in Padang Mangateh

(source:https://www.infosumbar.net) artikel/dilema-wisata-padang-mangateh/)

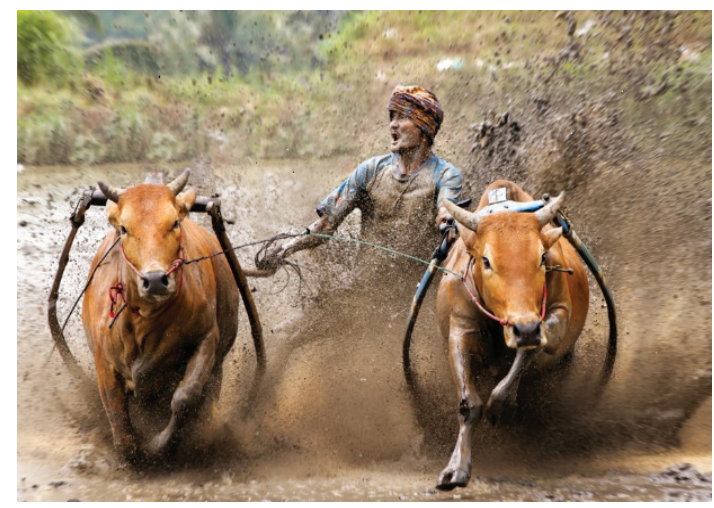

Figure 7. Traditional event "pacujawi" (Source:https://dularif.deviantart.com/art) Pacu-Jawi-2867020010)

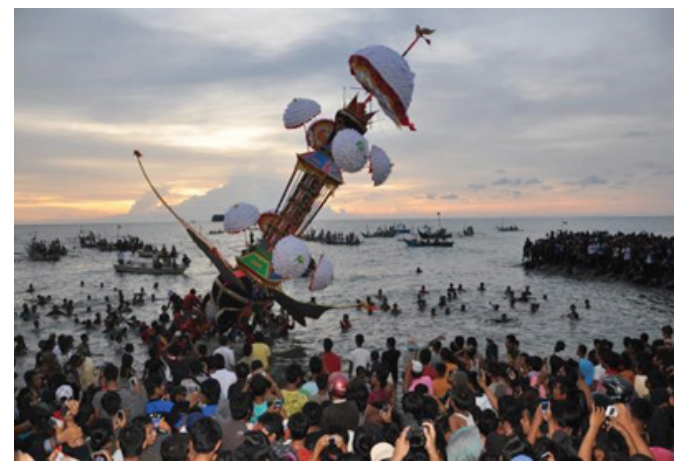

Figure 8. Traditional event "Tabuik" (source: http://www.indonesia.travel/en/ post/the-impressive-tabuik-festival-inpariaman-west-sumatra)

Tabuik is a cultural event which held every year in Pariaman, West Sumatera. This cultural party is also an opportunity to promote nature and marine tourism. Initially, this tradition is managed by the local community, but lately it has become an annual event that is scheduled by the government. This cultural tradition even managed to attract tourists or for photography.

\section{The Role of Triple Helix Actors in Promoting Successful Agro-tourism Sustainable Development in West Sumatera}

Promoting successful agro-tourism sustainable development is important since agro-tourism is mainly based on attractions and activities that are related to natural environment, historical heritage, and patterns of cultural regions. If these resources get harmed or destroyed, tourist resorts will not be able to attract tourists, and tourism will not be successful. Moreover, poor health conditions decrease economic and social benefits of tourism. Based on the research by Wildan, Sukardi and Syuaib (2016), tourism development must bring positive effect especially to local community, not only economically, but also socially and environmentally. Agro-tourism development should ideally be able to put local community as the leading actors in agro-tourism development based on their own social capital. Support from all related stakeholders such as business-intellectual-government (known as triple helix actor) is also needed because the development of agro-tourism is not possible to be done partially, but need to include all the triple helix stakeholders.

The development of agro-tourism should be done with the consideration of careful planning. It because not only the economic impact that it wants to be realized but also the long-term social and cultural sustainability. Based on that, this research also tried to analyze stakeholders' perspectives on their role which can be done for the development of agrotourism in West Sumatera. Focus group discussion founds a number of expected roles from each stakeholder and the importance of synergies and collaboration in performing those roles. This can be illustrated in the Figure 9.

The academician plays a role as a producer of knowledge and scientific research all the time. Academicians as an agent of development accelerate local economic growth and local communities. The academicians form a constructive values for 
the development of agro-tourism. Intellectual property as a part of the scholarly community in the institutions of higher education and research institutions has a major role in the process of participatory planning and public decision making of agrotourism development.

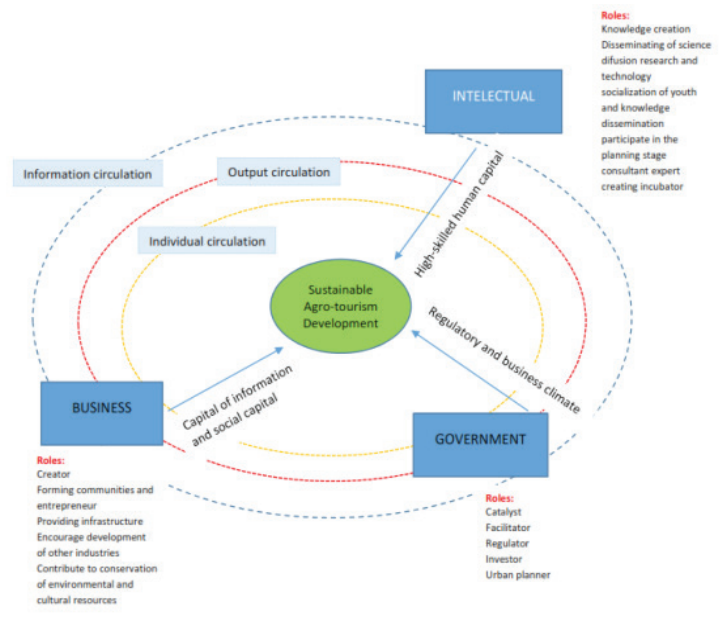

Figure 9.Triple Helix Analysis Model for Agro-Tourism Development

Intellectual institution is also an agent of change that bridges the effort to fulfill the public interest and relevance to local economic development. The various relationships, networking, and involvement of actors in agro-tourism development need institution to play a positive role to bridge the public interest in developing agro-tourism sphere, local economic growth, and community empowerment.

The continuous capacity of the institution to provide educated labor with new ideas, skills, and entrepreneurial talent has become a significant asset in the knowledge society (Ranga and Etzkowitz, 2012). The role of education is intended to encourage the birth of creative generation with the mindset that supports the growth initiative and work in the agro-tourism industries. The entrepreneurial academicians should participate in agrotourism development in their regions. Entrepreneurship as an academic mission is integrated with teaching and research. As the institution assumes an entrepreneurial role internally, it also naturally becomes more closely involved with industry, especially since there is not such a great distance between the institutional spheres. The purposes of conducting a research are to provide an input on the development of agro-tourism policy models and instruments needed, to produce technologies that support the operations and the efficient use of resources, and create a competitive agro-tourism industry. Through research, university's role to promote of agro-tourism is by studying the local area (Dragulanescu, 2012), researching and monitoring of rural tourism activities, and action to protect and conserve the environment and tourism resources. Through community service activities, the university can support the development of agro-tourism through the formation of local community initiatives and providing consultation of experts and the public in the development of agro-tourism and local economy. The role of community service carried out to form a society with institutions/ social order that supports the flourishing agro-tourism nationwide. In carrying out its role actively, scholars are required to have a disciplinary and high experimental spirit, have contrasted opinions (with empathy and ethics), able to solve problems, able to run cross-sector observations, able to use ICT technologies fluently, and become a member forum of science enrichment science and art both nationally and internationally, formally and informally.

Actors of businesses such as entrepreneurs, investors and creators of new technologies play a crucial role in formatting "economic capital" like entrepreneurship, technology, products, and driving force of innovation. Business is seen as the driving force of innovation along with the other two institutional spheres. The roles of businessman in the agro-tourism development are (a) As a creator which develop and promote the rural and agricultural culture, upgrade the environment, recycle or reuse resources, create a new market which can absorb the products and services, and also create jobs;(b) Forming communities and entrepreneur as a motor which involve the public in sharing ideas, mentoring activity that can hone creativity in doing business in agro-tourism industries, business coaching, and management training business in the agro-tourism industries; (c) Contribute to the cost of providing economic, cultural and social infrastructure; (d) Encourage the development of other industrial sectors, diversify local industry base, and improving business revenue growth; (e) contribute to the conversation of environmental, social, and cultural resources.

Government plays the major role in 'driving' academician and industry. Government is not only responsible to set the rules of the game but also provide the available venture capital to help grow 
new enterprises. Government's role in encouraging the growth of local initiatives in the development of agro-tourism is by empowering rural communities, especially through better management of agro-tourism business. The government creates a system which defines and regulates the formation of agro-tourism enterprises. Experts believe that the progress of the construction of the agro-tourism is strongly influenced by the location (synonymous with autonomy), and tolerance/creative mindset (synonymous with democracy).

Agro-tourism literature indicates that its development is closely associated with the economic development, increasing public employment, enhancing incomes, bring more business opportunities for local development, enlarging tax bases, urbanization, and improving business revenue growth. Agrotourism is a new industry for rural areas which introduce some characteristics of urban economies such as modern business management practices. Agro-tourism is a multi-faceted activity rooted in social, economic, and environmental resources. It can take benefits from various cultural, social, environmental, and economic resources to develop cultural and environmental tourism products. While the principles of good governance, participation, responsiveness, efficiency, professionalism, stimulus for conserving, protecting and improving natural environment, preservation of local culture and embedded in a socio-economic base in the use of rural space are the principles which can grow the agro-tourism industries aggressively.

The government should have a sensitivity and appreciation of people's aspirations. They should understand that in building intelligent persons in Indonesia can't be executed only in the short term. It means that there is a process of learning intelligence development, breeding, and enriching. Pursuing the final results in the short term without a strong pillar-based development will create a weak and unsustainable economic structure.

For that reason, government actors should be able to put the participatory planning and transparent interaction with other actors in the spirit of achieving the equality. The main roles of the Government in the development of agro-tourism are (a) government has the responsibility to create an environment which provides maximum benefit to all stakeholders of the development of agro-tourism region and minimizing negative impacts. Government as a regulator generates policies relating to people, industry, institution, intermediation, resources and technology. Government has the responsibility to provide the rules of the game and set policies that create a conducive climate business for the agrotourism development; (b) government as facilitator and advocate provides stimulation and encouragement business ideas in order to create destination competitiveness. It is not always support by giving financial assistance, incentives or protection, but providing government's leadership in agro-tourism development and public sector commitment to agro-tourism training, and referring to a need for an active government role in facilitating destination development; (c) Government as an investor should be able to develop a supply of indigenous tourism entrepreneurs by looking for opportunities in the market, creating a favorable entrepreneurial climate, attracting investors to the region, and responsible for infrastructure investment; (d) urban planner. In order to develop agrotourism and running it well, government has an essential role in strategic-level decisions of e.g. land use and zoning policies.

Collaboration between two or all three helices can be embodied in the incubator concept. Incubator concept focused on high-tech formation based upon academic research. Having realized that the essential purpose of an incubator was to teach a group of person to act as an organization, extension of the classic educational mission of the university as well as an expression of its new economic and social development remit, the model was applied to a variety of purposes with and without academician. Industrial associations entered the field, created incubators to expand traditional clusters. Municipalities also established incubators as a job creation strategy. An NGO, in collaboration with a university high-tech incubator, applied the model to organize cooperatives, training poor people from the favelas to run their own organizations and create jobs for themselves.

The formation and development of the consensus space can be accelerated by strengthening the dialogue and collaboration between national and regional innovation stakeholders, creating new platforms of communication, promoting collaborative governance measures such as public consultation and feedback, and collaborative leadership models and practices. 
Table 1

The Role of Triple Helix in Enhancing Agro-tourism Development

\begin{tabular}{|c|c|}
\hline Triple Helix & The Role \\
\hline Academicians & $\begin{array}{l}\text { Producer of knowledge and } \\
\text { scientific research } \\
\text { Diffusion technology } \\
\text { Participate in the process of } \\
\text { participatory planning and } \\
\text { public decision making } \\
\text { Provide consultation of experts } \\
\text { Creating incubator business }\end{array}$ \\
\hline
\end{tabular}

Businessman Creator of entrepreneurship, technology, products, and driving force of innovation Encourage the development of other industrial sectors Contribute to conservation of environmental and cultural resources

$\begin{array}{ll}\text { Government } & \text { Regulators } \\ & \text { Facilitator and advocate } \\ & \text { Investor } \\ & \text { Urban planner }\end{array}$

Source: Author, 2015

\section{Conclusions}

Agro-tourism development is one of many pro-poor strategies which has success stories in reducing poverty and bring positive impact to local economy. The development of agro-tourism based on natural resources, uniqueness flora and fauna and specific local social culture requires a holistic and multi-perspective approach to ensure that the benefits of agro-tourism are not only for economics but also not harmful to the natural, social and cultural environment of society in the long run.

The successful innovation of agrotourism development could not go partially, there must be collaboration among the academicians, the businessman, and the government (triple helix). The collaboration among three actors requires awareness of their roles so that mutual collaboration can support the sustainable development of agrotourism in West Sumatera.

The results of this research are expected to provide recommendations for the integration of many stakeholders in building synergy and cooperation in achieving development of sustainable agro-tourism. In the future, the research will extend to make a possible integration of triple helix models into "quadruple helix models" by adding "public" as the fourth helix. It would be specifically defined as the "media-based and culturalbased public and civil society.

\section{Acknowledgements}

This research was conducted under the research project of LPPM Universitas Andalas, funded by Kementrian Riset, Teknologi dan Pendidikan Tinggi 2015.

\section{References}

Dragulanescu, I, V,. and Drutu, M.(2012). Rural Tourism For Local Economic Development. International Journal of academic Research In Accounting, Finance and Management Science. Vol 2 (2012) pp. 196-203

Etzkowitz, H and Leydesdorff,L(1998). Triple Helix of Innovation: Introduction, Science and Public Policy 25 (6): 358-364

Godin, B. and Gingras, Y. (2000). The Place of Universities In The System of Knowledge Production. Research Policy, 29(2), 273278

Laydesdorff, L. (2012). The Triple Helix of University-Industry-Government Relations.http://www.leydesdorff.net/ th12/th12.pdf) diunduhpada 20 Agustus 2016

Leydesdorff, L. H. Etzkowitz. (1996). Emergence of a Triple Helix of University Industry-GovernmentRelations, Science and Public Policy 23 (5): pp. 279-286

Mahaliyanaarachchi, R, P,. (2015). AgroTourism as a Risk Management Strategy in Rural Agriculture Sector: With Special Reference to Developing Countries. The Journal of Agricultural Sciences Vol. 11, No. 1, January 2016. Pp. 1 - 12

Miles, M.S.; Huberman, A.M. (1984). Qualitative Data Analysis: A Sourcebookof Mew Methode. Baverly Hills: Sage Publications.

Muslim, Aziz. (2016) Economic Community Empowerment Throug Tourist Village Development. Jurnal Mimbar Vol 32; pp.343-352

Mutana, S. (2013). Rural tourism for propoor development in Zimbabwean rural communities: prospects in Binga rural district along Lake Kariba. International Journal of Advanced Research in Management and Social Sciences. Vol 2, No 4. Pp. 147-164

Ranga, M., Etzkowitz, H,. (2012). A Triple Helix System for Knowledge-based Regional Development: From "Spheres" 
to "Spaces". Stanford University, US

Risteski M., Kocevski, J., \&Arnaudov, K. (2012). Spatial planning and sustainable tourism as basis for developing competitive tourist destinations.Procedia - Social and Behavioral Sciences, 44, pp. 375 - 386.

Sarpong, D. Meissner D, Alexander E, Razak A. (2016). Organizing practices of university, industry and government that facilitate (or impede) the transition to a hybrid triple helix model of innovation. Technological Forecasting \& Social Change.

Wildan, Sukardi, Syuaib MZ. (2016). The Feasibility of Development of Social Capital-Based Ecotourism in West Lombok. Jurnal Mimbar 1pp. 214-222. 